Article

\title{
Too Many Cooks: Multiple International Principals Can Spoil the Quality of Governance
}

\author{
M. Rodwan Abouharb ${ }^{1, * \mathbb{C}}$, David Cingranelli ${ }^{2}$ and Mikhail Filippov ${ }^{2}$ \\ 1 Department of Political Science, University College of London, London WC1H 9QU, UK \\ 2 Department of Political Science, Binghamton University, SUNY, Binghamton, NY 13902-6000, USA; \\ davidc@binghamton.edu (D.C.); filippov@binghamton.edu (M.F.) \\ * Correspondence: m.abouharb@ucl.ac.uk; Tel.: +44-(0)207-679-4922
}

Received: 11 February 2019; Accepted: 11 April 2019; Published: 6 May 2019

\begin{abstract}
We contribute to the research stream emphasizing the competition between international organizations and citizens for influence over the domestic policy choices of national politicians. Drawing upon previous theoretical and empirical work on the common agency problem, we contend that the joint influence of a country's memberships in multiple international governmental organizations (IGOs) generates consistent, unintended, disruptive effects, which reduces domestic accountability and can worsen the quality of a domestic government. Even if we assume that joining any particular IGO is beneficial for member states, the competing demands of multiple IGO memberships could undermine the quality of their governments. Our comparative, cross-national empirical findings support this theoretical expectation. Countries participating in a larger number of IGOs tend to have poorer scores on five widely used indicators of the quality of a domestic government. Future research should identify the types of policies and countries where the negative externalities of international cooperation on domestic accountability are greatest.
\end{abstract}

Keywords: multiple principals; international governmental organizations; domestic accountability; agency loss; quality of domestic government

\section{Introduction}

We cannot fully understand politics and policymaking within countries without considering the linkages between national and international actors (Gourevitch 1978; Putnam 1988; Keohane 2009). In this paper, we focus on the effects of international governmental organizations (IGOs) on the quality of domestic government ${ }^{1}$. In our theoretical framework, membership in multiple IGOs necessitates a trade-off between gains achieved from international cooperation and an inevitable loss of domestic accountability. We build on the idea that IGOs may be viewed as principals or as "would be principals" (Keohane 2003, p. 140) that increasingly make demands for the attention of domestic politicians. To the degree that IGOs can sanction or reward policy choices of domestic politicians (agents), they compete with citizens and domestic institutions (domestic principals) to hold politicians accountable. We emphasize that such competition provides domestic politicians with greater opportunities to shirk their responsibilities, to engage in rent seeking, and to act with greater autonomy (Bourguignon and Sundberg 2007; Knack 2001; Knack and Rahman 2007; Mansfield and Pevehouse 2006; Moravcsik 1994; Papadopoulos 2010).

Our argument is consistent with the well-known English language idiom that "too many cooks spoil the broth". This idiom refers to the fact that that too many persons in the kitchen, each adding

1 We use the terms quality of domestic government and quality of government interchangeably. 
their own ingredient, will produce a soup that tastes awful. More generally, if too many persons (or principals) participate in performing any task (or contribute instructions to those who must perform the task), the task will not be done very well. Following this logic, we contend that the joint influence of a country's memberships in multiple IGOs, each of which generates its own set of rules and incentives, produces consistent, unintended, disruptive effects on domestic accountability. Less accountability reduces the quality of domestic government. ${ }^{2}$

The main purpose of our paper is to present the increasing competition between citizens and IGOs for the attention of domestic politicians as a version of the multiple principals, common agent problem. This problem has been linked to agency loss in a wide variety of substantive contexts. In this paper, we acknowledge that the benefits from IGO membership may be necessary to address some specific problems, but we argue that the demands made by multiple international principals could also make it more difficult for citizens to control domestic politicians. This is a counterintuitive claim that runs counter to the mainstream argument that multilateral cooperation including the kind that is facilitated by participation in IGOs is a good thing.

Readers are likely to be skeptical, as they should be. We are mainly concerned with developing the new theoretical argument, but we also provide some illustrative examples and statistical evidence. First, we highlight the increasing influence IGOs have even on powerful states. We discuss the effects of EU membership on domestic accountability. Some EU members may leave the organization because of this problem. Then we illustrate how and why the demands of multiple IGOs provides additional opportunities for domestic agents to shirk their responsibilities to their citizens. We show that economic development demands made by the International Monetary Fund (IMF) and the United Nations (UN) on poorer countries often conflict and must be reconciled by domestic politicians.

Finally, using large-scale, comparative, cross-national statistical analysis, we demonstrate that, on average, a larger number of IGO memberships is associated with a lower quality of government (QOG), other things being equal. To further interrogate this statistical finding, we examine the effects of membership in powerful versus weak intergovernmental organizations. As a test of robustness of our findings, we separate the IGO memberships of each country into two groups-powerful (the World Trade Organization (WTO), the IMF, and the World Bank) and less powerful (all other memberships) - and show that the results hold. More memberships in both powerful and less powerful IGOs are associated with lower quality of government.

\section{Previous Research}

Most previous research argues the opposite-that greater political and economic cooperation, including participation in IGOs, leads to improved governance and locks politicians into policies necessary to improve economic and social outcomes (Abbott and Snidal 1998; Moravcsik 2000; Dreher and Voigt 2011; Fang and Owen 2011; Bauhr and Nasiritousi 2012; Von Stein 2016; Vreeland 2003; Carrubba and Gabel 2017). Previous inquiries have also linked the activities of international actors to improved domestic outcomes in a variety of specific policy areas (Waltz 1999; Potrafke 2015). Those policies include better human rights practices (Greenhill 2010, 2016; Greenhill et al. 2009; Dreher et al. 2012), gender equality (Meyer 2003; Richards and Gelleny 2007; Neumayer and Soysa 2011), stricter environmental standards (Frank et al. 2000; Young 2011; Spilker 2012), better public health (Clavier and Leeuw 2013), improved government transparency (Mansfield et al. 2002; Grigorescu 2003), democratization (Pevehouse 2002; Mansfield and Pevehouse 2006), and enhanced constitutional democracy (Keohane et al. 2009).

2 In addition to the loss in domestic accountability, which is our focus, there are many other closely related problems, including losses in representation, transparency, cost-efficiency, expediency, public participation in decision-making, the accountability of international organizations, and the democratic deficit. 
More generally, international actors, multilateralism, and increased global connections have been theorized as positively affecting the quality of domestic government at least under some circumstances. Keohane et al. (2009) noted that multilateralism has a positive effect on constitutional democracy by combating special interests, protecting individual and minority rights, and fostering collective deliberation. They also make clear that any judgement about these processes rests on an empirical examination of the democratic consequences of multilateralism.

A few studies do highlight potential negative consequences of international cooperation on domestic politics and policy. Some scholars believe that multilateral organizations are highly politicalized and question the ability of these organizations to enhance procedural democracy, arguing that powerful interests created international institutions with the view to promoting their own welfare and stability (Gartzke and Naoi 2011, p. 594). When multilateral organizations do seek to influence domestic politics, it is to disproportionately affect less powerful countries. In particular, these multilateral organizations can weaken popular rule and empower special interests, which then undermines domestic majoritarian preferences while leaving powerful special interest groups largely unaffected (Gartzke and Naoi 2011, pp. 594, 598).

Recent research argues that it is getting even more difficult for member states to control the bureaucracy of international organizations as the number of IGOs and the complexity of their interorganizational relations increases (Lipson 2017). There are also dysfunctional effects when international organizations proliferate, because they compete with each other and duplicate functions (Drezner 2009; Canavire-Bacarreza et al. 2015). The proliferation of aid donors can reduce the quality of domestic bureaucracy (Acharya et al. 2006), increase the amount of administrative work (Kilby 2011), and have a negative impact on administrative capacity in recipient countries (Knack and Rahman 2007). More generally, foreign aid can undermine incentives for better government in developing nations (Bourguignon and Sundberg 2007). With increases of aid, the political accountability of politicians to their own citizens declines (Knack 2001; Knack and Rahman 2007). The effectiveness of conditionality underpinning international aid packages and development assistance has been called into question (Abouharb and Cingranelli 2007; Smith 2007; Dreher 2009).

It is also important to acknowledge that most scholars treat states as principals and IGOs as agents. For example, there is a significant amount of literature discussing accountability of international organizations to their members (Grant and Keohane 2005; Copelovitch 2010; Dreher and Voigt 2011). In our analysis, IGOs are viewed as principals or as "would be principals" (Keohane 2003, p. 140). Consistent with our perspective, Barnett and Finnemore $(1999,2004)$ suggest that we conceptualize IGOs as semi-independent actors with their own bureaucratic goals that could be distinctive even from the goals of the most powerful members. In particular, powerful states may create most international organizations, but once established, those organizations do not act as straightforward servants of the states that created them (Bauer et al. 2016).

\section{The Argument}

According to Schedler (1999, p. 17), "A is accountable to B when A is obliged to inform B about A's (past or future) actions and decisions, to justify them, and to suffer punishment in the case of eventual misconduct". Governments are accountable if domestic actors "can discern whether governments are acting in their interest and sanction them appropriately" (Przeworski et al. 1999, p. 40). The literature has concluded that a high level of accountability is very important, if not necessary, for achieving a high quality of domestic government (Bovens et al. 2014; Koop and Hanretty 2018). ${ }^{3}$ However, politicians prefer greater autonomy, and accountability limits the autonomy of politicians. Accountability induces public officials "to make their actions relatively controllable by their principals, in order to attract resources and support" Ferejohn (1999, p. 133). We contend that IGO membership

3 For a review of this literature, see Lederman et al. (2005). 
complicates government, reduces transparency about government decision making, undermines domestic accountability, increases opportunities for shirking, and, therefore, reduces the quality of government.

Following Fukuyama (2013), we use the term "quality of government" to refer to a national government's ability to make and enforce rules. A popular approach is to conceptualize government in a principal-agent framework and, within such a framework, "the quality of government is different from the ends that government is meant to fulfil. That is government is about the performance of agents in carrying out the wishes of principals, and not about the goals that principals set" (Fukuyama 2013, p. 350; Rothstein and Teorell 2008). The quality of government is higher when there are fewer incentives for politicians to engage in venal, greedy, corrupt, and rent-seeking methods of governing (De Mesquita et al. 2005a, p. 485).

As noted, we build on the idea that IGOs can act as principals or "would be" principals (Keohane 2003, p. 140) competing with domestic actors for the attention and accountability of national politicians. A principal is an actor who can make decisions that affect the incentives of an agent to choose among possible actions. A principal-agent relationship is often defined in formal terms described in a contract. How and to what extent a principal can structure incentives for the agent is the central focus of the principal agent theoretical framework (Gailmard 2009). The premise of our argument is that, as international organizations become more influential over time, they can more efficiently sanction or reward the domestic policy choices of national politicians. Thus, from a domestic perspective, each IGO membership introduces a new principal or "would be" principal.

The effect of IGOs on domestic government could be analyzed as a version of a multiple principals, common agency problem. The term "multiple principals" refers to a situation in which agents have contracts with more than one principal. The "common agency" refers to situations when "the action chosen by a particular individual (the agent) affects not just one, but several other parties (the principals), whose preferences for the various possible actions typically conflict" (Bernheim and Whinston 1986, p. 923). The principals are aware of each other, but to the extent principals do not coordinate their transactions with the agent, "common agency generally incurs social costs (because of externalities between principals)" (Holmstrom and Milgrom 1988, p. 1). In our case, the competition between citizens as the chief principal and the international (would be) principals creates conflicts in incentives for the agent (the domestic government) and increases opportunities for shirking.

We have made several simplifying assumptions. First, we assumed that both domestic actors and international actors have a stake in the actions of domestic politicians. Second, both domestic and international actors can impose certain rewards and costs on domestic politicians. Third, we assumed that domestic and international actors have distinctive criteria for evaluating national politicians. Under such assumptions, the control of domestic politicians can be analyzed as a common agency model where an agent (in this case, domestic politicians or a national government) ${ }^{4}$ performs multiple tasks while serving multiple principals. Each principal differs in the relative value it places on each task (Bernheim and Whinston 1986; Holmstrom and Milgrom 1991; Dewatripont et al. 2000), and every principal encourages the government to pour its effort into the activities it values the most.

Consider a situation with multiple principals and a common agent, where the agent faces a set of separate contracts, each one designed to align the agent's preferences with those of a specific principal. Each principal compensates the agent for performing certain tasks that are useful to the principal and cost the agent in effort. Since the performance is costly to monitor, and because there is uncertainty and risk, the principal does not observe all the agent's efforts. As a result, no principal ever gets first-best compliance from the agent. Moreover, divergent preferences among multiple principals who compete for the attention of the common agent produce bilateral contracts that result in even lower incentives

4 We use the terms "domestic politicians" and "national government" interchangeably. 
for the agent to completely fulfil any particular contract (Sinclair-Desgagné 2001, p. 11; Gailmard 2009; Gulzar and Pasquale 2017). ${ }^{5}$

A linear reward scheme is an illustration of compensations to the common agent (a domestic government) in return for its performance. Each principal $i$ gives the agent a fixed benefit $k_{i}$ and in addition tries to keep the government "accountable" though provision of a marginal reward or bonus $m_{i}$ per unit of $x_{i}$ (performance) produced, for a total benefit of $y\left(x_{i}\right)=k_{i}+m_{i} x_{i}$. For simplicity, we could assume that each principal $i$ benefits only from $x_{i}$ and rewards the agent only for the effort $e_{i}$ aimed to produce the outcome $x_{i}$. Suppose that:

(1) The outcome $x_{i}$ equals the agent's effort $e_{i}$ plus a normally distributed error (e.g., $x_{i}=e_{i}+\varepsilon_{i}$, for $i=1,2, \ldots n)$ and the errors $\varepsilon_{i}$ are independent with variance $v$;

(2) the agent's cost of effort is quadratic (e.g., $\left.C\left(e_{1}, e_{2}, \ldots e_{n}\right)=\left(1 / 2 c e_{1}\right)^{2}+\left(1 / 2 c e_{2}\right)^{2}+\ldots\left(1 / 2 c e_{n}\right)^{2}\right)$; and

(3) the principals are all risk-neutral, but the agent's risk aversion is $r$.

As Dixit (2002) demonstrated, such a linear reward scheme is optimal (the Nash equilibrium) when the sum of the marginal payment coefficients $m_{i}$ is equal to:

$$
m=1 /(1+N c v r) \text {. }
$$

Thus, the existence of several principals $(N)$ could significantly reduce the overall incentives (accountability) of a risk-averse agent (government). By extension, when states participate in multiple international agreements, there will be additional agency loss for domestic actors, because participation in each new IGO introduces a new principal with a new set of obligations.

The theoretical connection between accountability and the quality of government is well established in the literature (Adsera et al. 2003; Gailmard 2009; Laffont and Martimort 2009). The theory emphasizes the crucial role of informational asymmetries between citizens and policymakers. Government officials always have incentives to engage in various forms of rent-seeking, because their actions are only partly observable by citizens. The lower the political accountability, the more attractive and widespread the rent-seeking becomes, thus reducing the quality of government (Bovens et al. 2014; Fortunato and Panizza 2015; Mauro 1995; Pellegrini 2011; Treisman 2000; Rothstein and Teorell 2008).

The quality of government is expected to be higher in democratic regimes, because elections help to hold politicians accountable to their citizens (but see (Manzetti and Wilson 2007; Bowler 2017; Bauhr and Charron 2018)). Relying on a principal-agent model, Adsera et al. (2003) demonstrated that the quality of government is a function of the degree of domestic accountability in both democratic and authoritarian regimes. However, the costs of overthrowing a dictator are much higher than the costs of removing a leader through democratic elections, so the quality of government is expected to be higher in democracies. They also argued that quality of government should be higher in wealthier countries (Adsera et al. 2003, p. 448). In addition, a number of structural and political factors also could promote political accountability and, therefore, contribute to better government (Adsera et al. 2003).

It is also widely understood that more transparency about government decision-making increases the quality of government. Information about the actions of governments is important to hold politicians accountable. Government officials have less opportunity to shirk their responsibilities when citizens have more precise knowledge about why officials adopted policies and how they plan to implement them. It follows that factors reducing citizens' knowledge about the policymaking process decreases the level of domestic accountability. In a seminal article, Powell and Whitten (1993) argued that complex governmental and institutional structures could distort the clarity of political responsibility, thus making it more difficult for citizens to blame and sanction their governments for poor performance. In subsequent work, scholars moved towards a more general understanding of

5 Formally defined, in this context, "lower incentives" mean that the agent's overall payoff would turn out to be relatively insensitive to the outcome (Laffont and Martimort 2009). 
how complexity of government undermines domestic accountability (e.g., Anderson 2006; Tavits 2007; Hellwig and Samuels 2008; Hobolt et al. 2013). We contend that IGO membership complicates government, reduces transparency about government decision making, undermines domestic accountability, and, therefore, reduces the quality of government.

While there is always some agency loss between principal and agent, we emphasize that participation in more IGOs contributes to additional losses in domestic accountability, other things equal. It is more difficult for citizens to assess the relative importance of their demands on their governments' decision-making calculus when their governments also face competing pressures arising from membership in increasing numbers of intergovernmental organizations. The added demands directed at governments which arise from membership in IGOs make it more difficult for citizens to hold their domestic officials accountable for their decisions. This is because political leaders have greater flexibility to blame the demands of intergovernmental organizations for their failure to deliver good government. Any decline in accountability undermines the incentives of domestic politicians to devote their efforts towards improving the quality of government. The negative influence on domestic government we identify is an inevitable externality-an unintended consequence of international actors seeking to influence national governments. One empirical implication of our theoretical argument is that more IGO memberships will be associated with indicators showing a lower quality of government.

\section{Examples of IGO Influence on National Governments}

The European Union is the most discussed case of IGO membership having strong influence on the domestic politics and policies of member states. Various versions of the common agency argument have been used to explain the decline of accountability of politicians to their citizens because of increasing influence of the European Union (Hix 2002; Dehousse 2008; Karlsson et al. 2009; Lindstädt et al. 2012; Scharpf 2013). More generally, Papadopoulos (2010) argued that the trend towards greater international cooperation and the rise of multilevel government can have negative consequences for domestic democratic accountability. In the case of the European Union, Mair (2013, p. 145) noted that the national governments as "agents may sometimes even be persuaded that they owe a greater duty of accountability to these 'external' principals than to their own domestic principals".

Even the United States sometimes finds it difficult to resist the rulings of powerful intergovernmental organizations. For example, former President Bush made a number of protectionist promises to the steel industry and its workforce in swing states like Ohio, Pennsylvania, and West Virginia (Sanger and Kahn 2002). Pursuant to these promises, in March 2002, Bush levied tariffs on imports of foreign steel into the US market. One year later, the WTO ruled against those tariffs, and the Bush administration complied with the ruling (Tran 2003). Celebrating this outcome, EU Trade Commissioner Pascal Lamy boasted that the WTO provides "a mechanism respected by the biggest of elephants" (Ackman 2003).

It is more difficult for politicians in less powerful nations to ignore the increasing authority of intergovernmental organizations. In particular, politicians in developing countries regularly depend on financial assistance provided by the IMF and World Bank, often on a negotiated, and, therefore, conditional basis (Vreeland 2003). The Bank and Fund exert control on the choices of national politicians through the conditions associated with their lending programs. One of the most frequently used are structural adjustment programs where governments in economic need must agree to a variety of economic reforms in return for loans. More generally, international actors influence national governments by establishing metrics to evaluate the compliance of states with their norms and obligations (Abbott et al. 2015; Broome and Quirk 2015; Merry et al. 2015). Creating and disseminating numerical indicators comparing states, as many IGOs do, constitutes an exercise of social power that rewards and punishes states based on whether they conform with international norms (Merry et al. 2015).

Though IGOs including the IMF and World Bank may value higher quality of government, they usually have other priorities. The IMF and World Bank focus on international and national economic stability and economic growth. Other IGOs concentrate on achieving good outcomes in a specific policy 
area, such as promoting mutual defense, combatting transnational organized crime, reducing global warming, or promoting and implementing laws of the sea. Those priorities often create conflicting demands for domestic politicians. For example, the World Bank and IMF typically require loan recipients to balance their budgets. Recipients are encouraged to privatize public services, raise the fees that people must pay for them, and reduce subsidies for education and health care. By contrast, the International Covenant on Economic, Social and Cultural Rights (ICESCR) demands that state parties give higher priority to providing citizens with better health, paying special attention to poor and marginalized people. According to Article 2(1) of the ICESCR, each state party is obligated "to take steps, ... to the maximum of its available resources, with a view to achieving progressively the full realization of the rights recognized ... including particularly the adoption of legislative measures." Thus, countries that have negotiated loan agreements with the IMF and have also ratified the ICESR must reconcile the competing demands of both IGOs. When domestic politicians decide what to do, they can pay attention to one IGO or the other, pay attention to both but to different degrees, follow the demands of their citizens, or strategically use the conflicting demands to avoid accountability.

Our argument applies to situations where a government is a member of several IGOs such as the IMF and the ICESCR that make multiple competing demands of member states. This problem is also addressed in the regime complexity and forum shopping literature (Raustiala and Victor 2004; Busch 2007; Alter and Meunier 2009; Orsini et al. 2013). The multiple principal, common agent problem also applies to situations where a government is a member of several IGOs that deal with different topics. In that situation, politicians can choose to which issues to devote most of their attention. Both situations allow politicians to shirk their responsibilities to their citizens.

Intergovernmental organizations are likely to be more influential than other international actors that seek to shape the policy choices of domestic politicians. Unlike domestic and international interest groups and lobbies, IGOs have explicit and public contracts with member states. Those contracts stipulate rules for member states within one or more domains of policy. To varying degrees, they have the authority to legitimately constrain the domestic policy choices of members. Altogether, they increasingly influence national governments through sanctioning or rewarding mechanisms.

Most countries have memberships in a diverse group of IGOs, and some IGOs are more able to affect the priorities of domestic politicians than others. However, it is difficult to determine objectively which IGOs have the most influence on domestic politicians. For the purposes of the empirical analysis, we adopt the assumption that, on average, the proportion of more and less influential IGOs each state joins is constant. Thus, we use the total number of memberships in IGOs for each state as a proxy for the influence of IGOs on national governments.

We hypothesized that joining a greater number of intergovernmental organizations will have a negative impact on the quality of government. In the empirical part of the paper, we used large-scale, comparative, cross-national statistical analysis to demonstrate that, on average, a larger number of IGO memberships is associated with a lower quality of government, other things being equal.

\section{Research Design}

The sample for this study consisted of up to 129 countries-all of the countries for which we have data for all variables for the period 1985-2005. The unit of analysis is the country-year. In the selection of the time period and the countries, we were constrained by the availability of data for our main independent variable, the total number of IGO memberships. The countries included are listed in Table A1 of the Appendix A.

\subsection{Dependent Variables}

Empirical research on the quality of government has employed numerous and diverse indicators (Langbein and Knack 2010), and we used five quality of government indicators in our empirical 
tests. ${ }^{6}$ The indicators we used link well to our arguments about the multiple principals, common agent problem and its consequences for the quality of government, as they capture different aspects of governance quality which we expect to worsen as the number of principals increases. Regressions using each of the five indicators produced similar results supporting our hypothesis. The first indicator we employed is a widely used metric designed to capture the overall quality of government—the quality of government index. ${ }^{7}$ It is computed as the average value of three ICRG variables: Corruption, law and order, and bureaucracy quality. It is scaled from 0 to 1 , with higher values indicating a higher quality of government (Dahlberg et al. 2019).

The quality of government index (provided by the ICRG) has a number of advantages over other indicators of the quality of government. It covers the longest period of time and comes from a single source, which minimizes over-time variation in the meaning of the scale. Other studies have used the ICRG data as indicators of the quality of government, making the results of our analysis comparable with theirs (Knack 2001; Knack and Rahman 2007; Charron and Lapuente 2010; Fortunato and Panizza 2015; Sundell 2015; Heller et al. 2016). We expected that the total number of IGO memberships held by each country would be negatively associated with the quality of government index.

We also employed four other indicators of the quality of government. ${ }^{8}$ Two of these-the control of corruption index and government effectiveness index-come from the World Bank's Worldwide Government database and have been commonly used in previous research. They are based on several hundred individual variables measuring perceptions of the quality of government. The control of corruption index measures perceptions of corruption, defined as the exercise of public power for private gain. The government effectiveness index combines variables measuring perceptions of the quality of the bureaucracy and other characteristics of government required for efficient government policies. These survey-based measures range from -2.5 to 2.5 , with higher scores representing higher quality of government. They have observations for a shorter period of time: 1995-2005. We expected that the total number of IGO memberships held by each country would be negatively associated with both the control of corruption index and government effectiveness index.

Finally, we employed two relatively new indices from the data set assembled by the Variety of Democracy (V-Dem) project-the political corruption index and the public sector corruption index. Those indices are based on country expert answers to questions about the pervasiveness of political corruption in a variety of government institutions and activities. ${ }^{9}$ They have observations for the entire period of our analysis. We expected that the total number of IGO memberships held by each country would be positively associated with both of these measures of corruption.

\subsection{Independent Predictors of Interest}

Our main independent variable was the total number of IGO memberships held by each country in each year. This variable was calculated based on Pevehouse et al. (2004). There was considerable variation in our main independent variable, total number of IGO memberships held by each country in each year. The mean number of IGOs in which a country participated during the time period of our analysis was $49(\mathrm{SD}=23.6)$.

Our hypothesis is subject to criticisms of reverse causality. Instead of membership in additional IGOs leading to a decrease in the quality of government, it could be that states with a low quality of government join IGOs to credibly commit themselves to better government. States might want to

6 See "Measuring the Quality of Government and Subnational Variation" by the Quality of Government Institute: http: //www.qog.pol.gu.se/digitalAssets/1358/1358344_final-report---parts-1-3.pdf.

7 This index is included in the International Country Risk Guide (ICRG). https://www.prsgroup.com/about-us/our-twomethodologies/icrg.

8 These indicators and indicators of all control variables are provided by the QOG Institute (Dahlberg et al. 2019).

9 Varieties of Democracy Dataset (V-Dem) is a collaboration among more than 50 scholars worldwide, which is co-hosted by the Department of Political Science at the University of Gothenburg, Sweden; and the Kellogg Institute at the University of Notre Dame, USA. For more details, see http://www.qogdata.pol.gu.se/data/qog_std_jan17.pdf. Regressions using other measures of corruption compiled by the V-Democracy Project as dependent variables produce similar results. 
commit themselves to win support from constituents who do not trust the current government or to satisfy conditions placed on them by the international community. There are no easy solutions to this endogeneity problem. To address questions about possible endogeneity and directional causality, we lagged the main independent variable by five years. This use of a five-year lag is admittedly ad hoc; it is the same lag used by De Mesquita et al. (2005b) and Bearce and Bondanella (2007). In the latter case, a five-year time lag was used to assess the effects of IGO membership. Using a three-year lag does not change our substantive results.

\subsection{Control Variables}

Our control variables included several factors found to be significant predictors of quality of government in previous research. Research has found that democratic regimes tend to have a higher quality of government (La Porta et al. 1999; Adsera et al. 2003). We included a measure of regime type: The Polity IV Score of institutionalized democracy (Marshall et al. 2018) to account for this possibility. The literature has also noted that wealthier countries tend to have a higher quality of government (La Porta et al. 1999; Adsera et al. 2003). With this in mind, we controlled for the level of wealth in a country using the logarithm of GDP per capita constant 2005 US\$ from the World Bank (2018).

The literature has identified a number of structural and political factors that also promote or reduce political accountability and, therefore, help to explain variations in quality of government (Adsera et al. 2003). The British legal system (Treisman 2000) and economic globalization (Dreher et al. 2007) have been shown to be associated with a higher QOG, so we included British legal origin taken from La Porta et al. (1999) and economic globalization, part of the KOF Globalisation Index (Dreher 2006; Gygli et al. 2019) as control variables. Previous studies have found that total natural resources rents (La Porta et al. 1999; Aidt 2003; Pellegrini and Gerlagh 2008) and ethnic fractionalization (Mauro 1995) were associated with lower quality of government, so we also included a measure of natural resources rents as a percentage of GDP from the World Bank (2018) and a measure of ethnic fractionalization taken from Alesina et al. (2003). Overall, the estimated coefficients of the control variables in our regression analyses either are statistically insignificant or are consistent with previous findings. ${ }^{10}$

Table A2 in the appendix shows that there was not a problem of multicollinearity among the independent variables. Table A3 in the appendix provides the descriptive statistics for all of the independent variables. Table A4 of the appendix provides a brief summary of each of the dependent variables used in the paper.

\section{Results}

In Table 1, we focus on our first dependent variable, the quality of government index. Here, we demonstrate the negative effect of membership in IGOs using four alternative statistical models. All models in Table 1 produce similar results that fully support our theoretical expectations. We started with two time-series cross-sectional fixed effects regressions. The fixed effects estimation reduces the likelihood of omitted variable bias, since it controls for the possible effects of both observable and unobservable time-constant variables. However, because of that, in fixed effects models, the time-invariant explanatory variables must be excluded. Model 1 with no control variables incorporates information from 138 countries for the period of 1985-2005. Model 2 includes all time variant control variables - the level of institutionalized democracy and the logarithm of real GDP per capita, the degree to which the economy depends upon the extraction of natural resources, and the degree of economic globalization. The independent variable of main theoretical interest, as noted above, is the total number of IGO memberships of each country. The sign of the total number of IGO memberships is negative and is statistically significant, as expected in both fixed effects regressions.

10 In our data, there is only a weak correlation between the main independent variable, the total number of IGO memberships, and the control variables. The correlation matrix of all independent variables is reported in Appendix A Table A2. 
Next, to control explicitly for various combinations of variables identified in the literature as important, we supplemented the fixed effects analysis with random effects time-series cross-sectional estimation (Model 3). We added controls for variables that are time-invariant in our sample: Ethnolinguistic fractionalization, British legal origin, and the dummy indicators for the world's regions. We also added a year counter as a way to control for trends in the independent variable. Finally, we estimated a Generalized Least Squares (GLS) regression with correction for panel-specific AR(1) autocorrelation and heteroskedastic error structure, while including all control variables (Model 4).

The results of all four regressions presented in Table 1 are fully consistent with our theoretical expectations. The sign of the total number of IGO memberships variable is always negative and statistically significant. The signs of the estimated coefficients of the control variables are consistent with the results reported by previous studies and are statistically significant in almost all cases. Note that Models 1 and 2 each explain about $85 \%$ of the variation in the quality of government.

Table 1. The effects of the number of international governmental organization (IGO) memberships on the International Country Risk Guide (ICRG) indicator of quality of government. Cross-section time-series models 1985-2005.

\begin{tabular}{|c|c|c|c|c|}
\hline & (1) & (2) & (3) & (4) \\
\hline VARIABLES & $\begin{array}{l}\text { Fixed Effects } \\
\text { Model I }\end{array}$ & $\begin{array}{l}\text { Fixed Effects } \\
\text { Model II }\end{array}$ & $\begin{array}{c}\text { Random } \\
\text { Effects Model }\end{array}$ & $\begin{array}{l}\text { GLS Model } \\
\text { AR(1) }\end{array}$ \\
\hline $\begin{array}{l}\text { Total Number of IGO Memberships, } \\
\text { 5-year Lag }\end{array}$ & $\begin{array}{l}-0.0008^{* * *} \\
(0.0001)\end{array}$ & $\begin{array}{l}-0.0005^{* *} \\
(0.0001)\end{array}$ & $\begin{array}{l}-0.0009^{* * *} \\
(0.0002)\end{array}$ & $\begin{array}{l}-0.0004^{* * *} \\
(0.0001)\end{array}$ \\
\hline Institutionalized Democracy & & $\begin{array}{l}0.003^{* *} \\
(0.001)\end{array}$ & $\begin{array}{c}0.005 * * * \\
(0.001)\end{array}$ & $\begin{array}{l}0.003 * * * \\
(0.0008)\end{array}$ \\
\hline GDP per capita (constant 2005 US\$), log & & $\begin{array}{c}0.06^{* * *} \\
(0.02)\end{array}$ & $\begin{array}{l}0.07^{* * *} \\
(0.008)\end{array}$ & $\begin{array}{c}0.06^{* * *} \\
(0.005)\end{array}$ \\
\hline Total natural resources rents ( $\%$ of GDP) & & $\begin{array}{c}-0.002 * * * \\
(0.0005)\end{array}$ & $\begin{array}{c}-0.002 * * * \\
(0.0004)\end{array}$ & $\begin{array}{c}-0.0008^{* * *} \\
(0.0002)\end{array}$ \\
\hline Economic Globalization & & $\begin{array}{l}-0.0005 \\
(0.0004)\end{array}$ & $\begin{array}{l}0.001 * * \\
(0.0004)\end{array}$ & $\begin{array}{c}0.0005^{* *} \\
(0.0002)\end{array}$ \\
\hline British Legal Origin & & & $\begin{array}{c}0.02 \\
(0.02) \\
\end{array}$ & $\begin{array}{c}0.04^{* *} \\
(0.01)\end{array}$ \\
\hline Ethnic Fractionalization & & & $\begin{array}{c}0.01 \\
(0.05)\end{array}$ & $\begin{array}{l}-0.01 \\
(0.03)\end{array}$ \\
\hline Year & & & $\begin{array}{c}-0.004^{* * *} \\
(0.0006)\end{array}$ & $\begin{array}{c}-0.003 * * * \\
(0.0005)\end{array}$ \\
\hline Dummies for Global Regions & & & Included & Included \\
\hline Constant & $\begin{array}{l}0.5^{* * *} \\
(0.02)\end{array}$ & $\begin{array}{c}0.1 \\
(0.1)\end{array}$ & $\begin{array}{c}8.1 * * * \\
(1.1)\end{array}$ & $\begin{array}{c}5.1 * * * \\
(1.0)\end{array}$ \\
\hline Observations & 2650 & 2111 & 2079 & 2077 \\
\hline R-squared & 0.85 & 0.84 & & \\
\hline Number of Countries & 138 & 118 & 115 & 113 \\
\hline
\end{tabular}

Standard errors in parentheses ${ }^{* * *} p<0.001,{ }^{* *} p<0.05$, and ${ }^{*} p<0.1$ refers to $1 \%, 5 \%$, and $10 \%$ significance level, respectively. Note: The dependent variable ranges from ZERO to ONE. Higher scores indicate better government performance. In our sample, the mean of the quality of government index is $0.56 ; \mathrm{SD}=0.23$.

Figure 1 helps to demonstrate the strong substantive effects of the number of IGO memberships on the quality of government by comparing those effects with the effects of democracy (based on the inclusion of all control variables, random effect Model 3). As noted above, many previous studies have shown that more democratic countries score higher on all metrics of the quality of government. Figure 1 shows that when the number of IGO memberships increases by approximately 23.6 (e.g., by one standard deviation), the decline in the quality of government is about equal to the effect that would be produced if the level of democracy declined by 5 points (on the ZERO to TEN scale). 


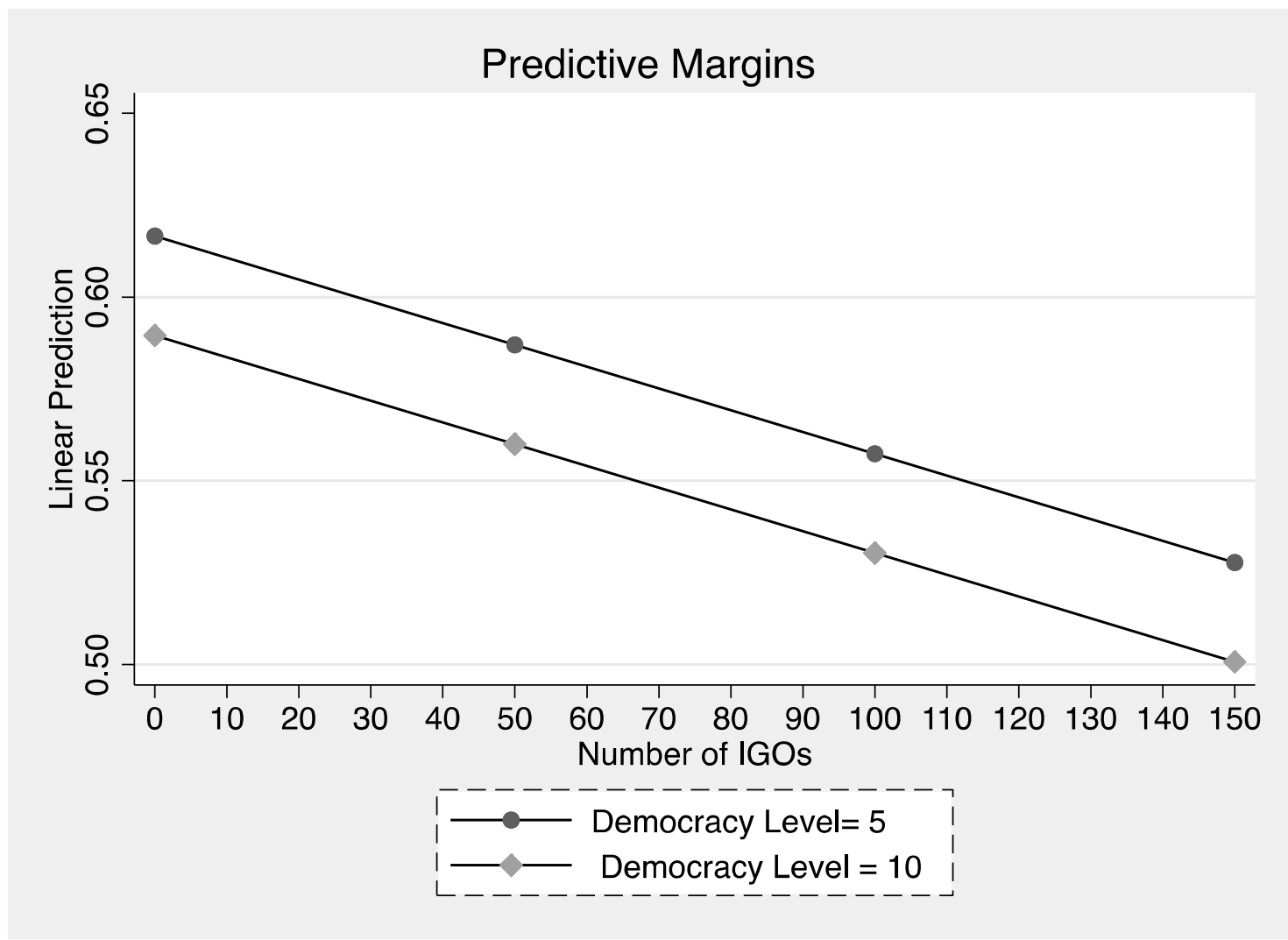

Figure 1. Fitted values of the quality of government index and democracy. Note: The dependent variable, The quality of government index, ranges from ZERO to ONE. Higher scores indicate better government performance. In our sample, the mean of the quality of government index is 0.56 ; $\mathrm{SD}=0.23$. The mean number of IGOs in which a country participated during the time period of our analysis is 49 (SD = 23.6).

Figure 2 compares the substantive effects of the number of IGO memberships on the quality of government with the effects of per capita income (again, based on the inclusion of all control variables, Model 3). As noted above, many previous studies also have shown that wealthier countries score higher on all metrics of the quality of government. Figure 2 shows that when the number of IGO memberships increases by approximately 50 , the decline in the quality of government is about equal to the effect that would be produced if the level of per capita income declined by $\$ 7500$ (from $\$ 16,500$ to $\$ 9000$ ).

Table 2 presents the GLS estimations for the full model (including all control variables) for four other indicators of the quality of government (Models 5-8). As noted above, the first two, control of corruption (Model 5) and government effectiveness (Model 6), are widely used, survey-based measures taken from the World Bank's Worldwide Government Indicators. The other two, the political corruption index and the public sector corruption index, are more recently created, expert-based indices created by the Variety of Democracy (V-Dem) project. Though these four additional indicators of quality of government capture different dimensions of government, the results for all four models regarding the effect of greater numbers of IGO memberships are all statistically significant and in the expected directions. Once again, the signs of the estimated coefficients of the control variables are consistent with the results reported by previous studies and with the results reported in Table 1. 


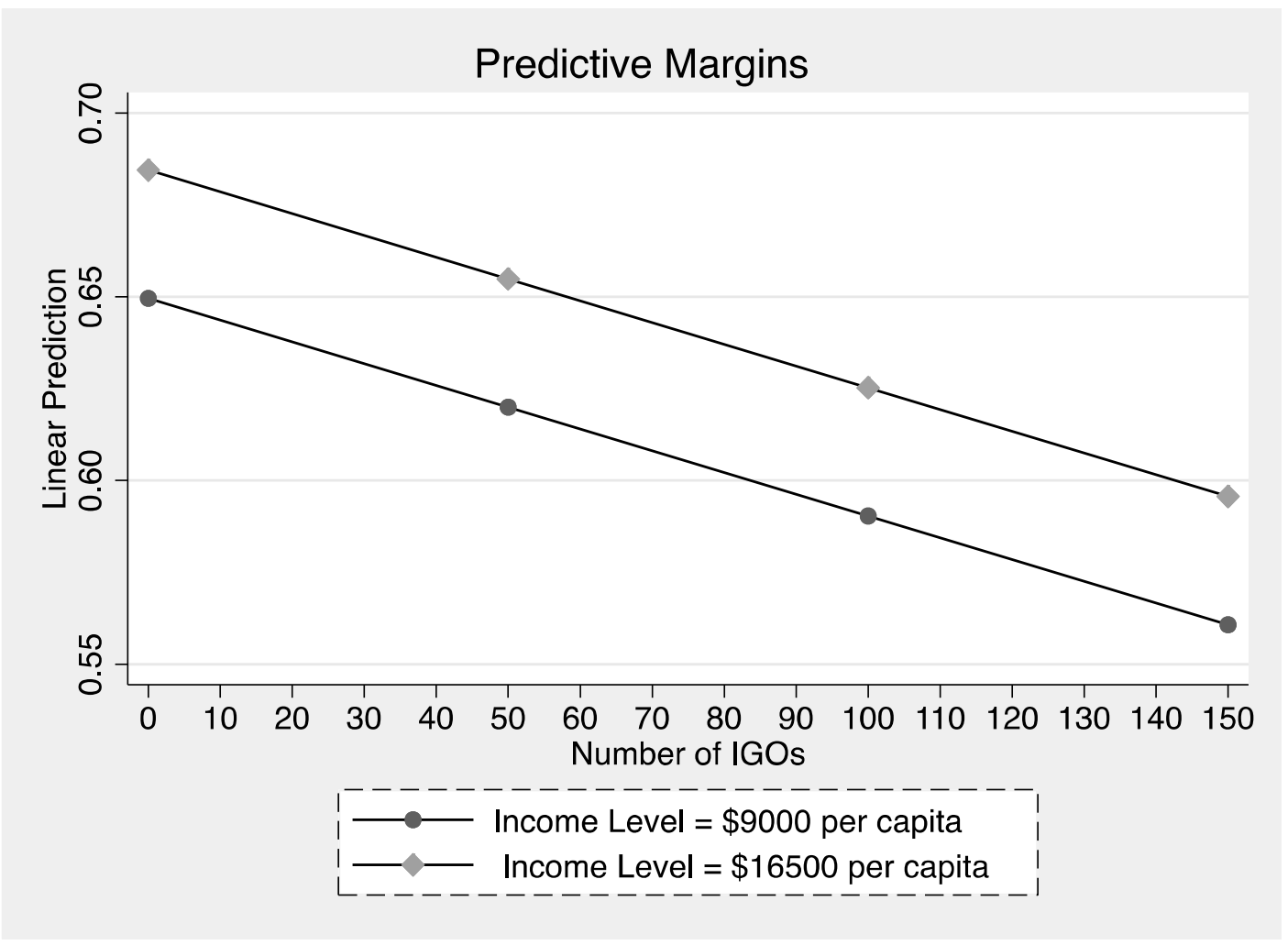

Figure 2. Fitted values of the quality of government index and income levels. Note: The dependent variable, The quality of government index, ranges from ZERO to ONE. Higher scores indicate better government performance. In our sample, the mean of the quality of government index is 0.56 ; $\mathrm{SD}=0.23$. The mean number of IGOs in which a country participated during the time period of our analysis is 49 (SD = 23.6).

Table 2. Four alternative dependent variables: Cross-section time-series models, GLS AR(1).

\begin{tabular}{|c|c|c|c|c|}
\hline & (5) & (6) & (7) & (8) \\
\hline VARIABLES & $\begin{array}{c}\text { Control of Corruption } \\
1996-2005\end{array}$ & $\begin{array}{l}\text { Government Effectiveness } \\
\text { 1996-2005 }\end{array}$ & $\begin{array}{l}\text { Political Corruption } \\
\quad 1985-2005\end{array}$ & $\begin{array}{l}\text { Public Sector Corruption } \\
\text { 1985-2005 }\end{array}$ \\
\hline $\begin{array}{l}\text { Total Number of IGO Memberships, } \\
\text { 5-year Lag }\end{array}$ & $\begin{array}{c}-0.002 * * \\
(0.0006)\end{array}$ & $\begin{array}{c}-0.001 * * \\
(0.0005)\end{array}$ & $\begin{array}{l}0.0002 * * * \\
(0.00004)\end{array}$ & $\begin{array}{l}0.0002 * * * \\
(0.00003)\end{array}$ \\
\hline Institutionalized Democracy & $\begin{array}{l}0.03 * * * \\
(0.004)\end{array}$ & $\begin{array}{c}0.03 * * * \\
(0.003)\end{array}$ & $\begin{array}{c}-0.006^{* * *} \\
(0.0005)\end{array}$ & $\begin{array}{c}-0.008^{* * *} \\
(0.0005)\end{array}$ \\
\hline GDP per capita (constant 2005 US\$), log & $\begin{array}{l}0.3^{* * *} \\
(0.01)\end{array}$ & $\begin{array}{l}0.3^{* * *} \\
(0.01)\end{array}$ & $\begin{array}{l}-0.08^{* * *} \\
(0.004)\end{array}$ & $\begin{array}{l}-0.07^{* * *} \\
(0.003)\end{array}$ \\
\hline Total natural resources rents ( $\%$ of GDP) & $\begin{array}{l}-0.009 \text { *** } \\
(0.0010)\end{array}$ & $\begin{array}{l}-0.01 * * * \\
(0.0008)\end{array}$ & $\begin{array}{l}0.001 * * * \\
(0.0001)\end{array}$ & $\begin{array}{l}0.0009^{* * *} \\
(0.0001)\end{array}$ \\
\hline Economic Globalization & $\begin{array}{l}0.01^{* * *} \\
(0.0010)\end{array}$ & $\begin{array}{l}0.008^{* * *} \\
(0.0008)\end{array}$ & $\begin{array}{l}-0.0008^{* * *} \\
(0.0001)\end{array}$ & $\begin{array}{l}-0.0003^{* * * *} \\
(0.00008)\end{array}$ \\
\hline British Legal Origin & $\begin{array}{c}0.02 \\
(0.03)\end{array}$ & $\begin{array}{l}0.08^{* *} \\
(0.03)\end{array}$ & $\begin{array}{l}-0.08^{* * * *} \\
(0.006)\end{array}$ & $\begin{array}{l}-0.04 * * * \\
(0.007)\end{array}$ \\
\hline Ethnic Fractionalization & $\begin{array}{c}0.03 \\
(0.08)\end{array}$ & $\begin{array}{l}0.2^{* *} \\
(0.05)\end{array}$ & $\begin{array}{l}0.1^{* * * *} \\
(0.01)\end{array}$ & $\begin{array}{l}0.04^{* *} \\
(0.02)\end{array}$ \\
\hline Year & $\begin{array}{l}-0.02 * * * \\
(0.002)\end{array}$ & $\begin{array}{l}-0.01 * * * \\
(0.002)\end{array}$ & $\begin{array}{l}0.004^{* * * *} \\
(0.0002)\end{array}$ & $\begin{array}{l}0.004^{* * *} \\
(0.0002)\end{array}$ \\
\hline Dummies for Global Regions & Included & Included & Included & Included \\
\hline Constant & $\begin{array}{c}35^{* * *} \\
(4.7)\end{array}$ & $\begin{array}{c}20^{* * * *} \\
(4.3)\end{array}$ & $\begin{array}{l}-7.4^{* * *} \\
(0.5)\end{array}$ & $\begin{array}{c}-6.5^{* * *} \\
(0.5)\end{array}$ \\
\hline Observations & 875 & 875 & 2295 & 2295 \\
\hline Number of Countries & 129 & 129 & 125 & 125 \\
\hline
\end{tabular}

Standard errors in parentheses ${ }^{* * *} p<0.001,{ }^{* *} p<0.05$, and ${ }^{*} p<0.1$ refers to $1 \%, 5 \%$, and $10 \%$ significance level, respectively. 


\section{Robustness Checks}

First, we tested the robustness of our results for less democratic and less economically developed countries. It is possible that in these types of countries, domestic accountability is relatively low anyway. Therefore, the demands of international organizations may not matter much. Table 3 presents the GLS estimations of the quality of government index for four subsets of countries electoral democracies (Model 9), nondemocracies (Model 10), OECD countries (Model 11), Non-OECD countries (Model 12), and Non-EU countries (Model 13). In all subsets, the relationship between the number of IGO memberships and the quality of government index is negative, as hypothesized.

Table 3. Dependent variable: ICRG indicator of quality of government in five subsets, cross-section time-series models, GLS AR(1), 1985-2005.

\begin{tabular}{|c|c|c|c|c|c|}
\hline & (9) & (10) & (11) & (12) & (13) \\
\hline VARIABLES & $\begin{array}{l}\text { Democratic Regimes } \\
\text { (Electoral Democracy) }\end{array}$ & $\begin{array}{l}\text { Non-Democratic } \\
\text { Regimes }\end{array}$ & OECD & Non-OECD & Non-EU \\
\hline $\begin{array}{l}\text { Total Number of IGO Memberships, } \\
\text { 5-year Lag }\end{array}$ & $\begin{array}{c}-0.0003 * * \\
(0.0001)\end{array}$ & $\begin{array}{c}-0.001 * * * \\
(0.0002)\end{array}$ & $\begin{array}{c}-0.0002 * \\
(0.0001)\end{array}$ & $\begin{array}{l}-0.001 * * * \\
(0.0002)\end{array}$ & $\begin{aligned}-0.0005^{* * *} & (0.0001)\end{aligned}$ \\
\hline Institutionalized Democracy & $\begin{array}{c}0.003 \\
(0.002)\end{array}$ & $\begin{array}{c}0.0006 \\
(0.0008)\end{array}$ & $\begin{array}{l}0.009 * * \\
(0.004)\end{array}$ & $\begin{array}{l}0.002 * * \\
(0.0009)\end{array}$ & $\begin{array}{l}0.003^{* * *} \\
(0.0008)\end{array}$ \\
\hline GDP per capita (constant 2005 US\$), log & $\begin{array}{l}0.09 * * * \\
(0.007)\end{array}$ & $\begin{array}{l}0.03^{* * *} \\
(0.007)\end{array}$ & $\begin{array}{l}0.2^{* * *} \\
(0.02)\end{array}$ & $\begin{array}{l}0.04^{* * *} \\
(0.006)\end{array}$ & $\begin{array}{l}0.06^{* * *} \\
(0.005)\end{array}$ \\
\hline Total natural resources rents ( $\%$ of GDP) & $\begin{array}{l}-0.0004 \\
(0.0004)\end{array}$ & $\begin{array}{c}-0.0007 * * * \\
(0.0002)\end{array}$ & $\begin{array}{c}0.0003 \\
(0.0007)\end{array}$ & $\begin{array}{c}-0.0008^{* * *} \\
(0.0002)\end{array}$ & $\begin{array}{l}-0.0010 * * * \\
(0.0002)\end{array}$ \\
\hline Economic Globalization & $\begin{array}{l}0.001 * * * \\
(0.0003)\end{array}$ & $\begin{array}{c}0.0009 * * * \\
(0.0003)\end{array}$ & $\begin{array}{l}0.0007 * \\
(0.0004)\end{array}$ & $\begin{array}{c}0.0006^{* *} \\
(0.0003)\end{array}$ & $\begin{array}{c}0.0006 \text { ** } \\
(0.0003)\end{array}$ \\
\hline British Legal Origin & $\begin{array}{c}0.06^{* * *} \\
(0.01)\end{array}$ & $\begin{array}{l}0.04^{* *} \\
(0.02)\end{array}$ & $\begin{array}{c}0.06^{* * *} \\
(0.02)\end{array}$ & $\begin{array}{l}0.03^{* *} \\
(0.01)\end{array}$ & $\begin{array}{l}0.02 \text { ** } \\
(0.008)\end{array}$ \\
\hline Ethnic Fractionalization & $\begin{array}{c}0.08 \text { ** } \\
(0.03)\end{array}$ & $\begin{array}{c}-0.006 \\
(0.05)\end{array}$ & $\begin{array}{l}-0.06 \\
(0.04)\end{array}$ & $\begin{array}{c}0.01 \\
(0.04)\end{array}$ & $\begin{array}{c}0.03 \\
(0.03)\end{array}$ \\
\hline Year & $\begin{array}{c}-0.005^{* * *} \\
(0.0006)\end{array}$ & $\begin{array}{c}-0.002 \text { ** } \\
(0.0006)\end{array}$ & $\begin{array}{c}-0.006^{* * *} \\
(0.0008)\end{array}$ & $\begin{array}{c}-0.002^{* *} \\
(0.0006)\end{array}$ & $\begin{array}{c}-0.003^{* * *} \\
(0.0005)\end{array}$ \\
\hline Dummies for Global Regions & Included & Included & Included & Included & Included \\
\hline Constant & $\begin{array}{c}8.7^{* * * *} \\
(1.2)\end{array}$ & $\begin{array}{l}3.4^{*} \\
(1.2)\end{array}$ & $\begin{array}{c}11 * * * \\
(1.5)\end{array}$ & $\begin{array}{c}3.6^{* *} \\
(1.3)\end{array}$ & $\begin{array}{c}5.0 * * * \\
(0.9)\end{array}$ \\
\hline Observations & 1268 & 805 & 580 & 1497 & 1825 \\
\hline Number of Countries & 81 & 59 & 32 & 81 & 102 \\
\hline
\end{tabular}

Standard errors in parentheses ${ }^{* * *} p<0.001,{ }^{* *} p<0.05$, and ${ }^{*} p<0.1$ refers to $1 \%, 5 \%$, and $10 \%$ significance level, respectively.

Second, we showed that the results are not due to state memberships in some important, powerful IGOs. The argument in this paper is that a nation's degree of involvement in the international system could have a negative externality on the quality of its domestic government. Thus, our main independent variable of theoretical interest is the total number of IGO memberships. We recognize that each country's mix of memberships may be important, too. The simplifying assumption that we made in the first part of our empirical analysis is that, on average, the proportion of more and less influential IGOs each state joins is constant. Some IGOs are more able to affect the policies and priorities of domestic politicians than others (Abouharb et al. 2015). To show that the results displayed above are not due to state memberships in important, powerful IGOs, Table 4 breaks IGO memberships into two groups-powerful (the WTO, the IMF, and the World Bank) and less powerful (all other memberships).

As shown in Table 4, the negative consequences of membership in many IGOs is not simply an artifact of each country's number of memberships in powerful IGOs (which can range from zero to three). The effects of membership in a higher number of powerful IGOs is negative or, in the case of control of corruption, statistically insignificant on the quality of domestic governance. The effect of the number of memberships in other IGOs is consistently negative. The signs and significance of the control variables do not change. 
Table 4. Separating membership in the International Monetary Fund (IMF), World Trade Organization (WTO), and World Bank (WB) from all other IGOs: GLS AR(1), cross-section time-series models.

\begin{tabular}{|c|c|c|c|c|c|}
\hline & (14) & (15) & (16) & (17) & (18) \\
\hline IMF, WTO and WB, 5-year Lag & $\begin{array}{c}-0.009 * * * \\
(0.003)\end{array}$ & $\begin{array}{c}0.02 \\
(0.01)\end{array}$ & $\begin{array}{c}-0.03^{* *} \\
(0.01)\end{array}$ & $\begin{array}{l}0.003^{* *} \\
(0.0008)\end{array}$ & $\begin{array}{c}0.0009 \\
(0.0007)\end{array}$ \\
\hline Institutionalized Democracy & $\begin{array}{l}0.004 * * * \\
(0.0008)\end{array}$ & $\begin{array}{l}0.03 \text { *** } \\
(0.004)\end{array}$ & $\begin{array}{l}0.03 * * * \\
(0.003)\end{array}$ & $\begin{array}{c}-0.006^{* * *} \\
(0.0005)\end{array}$ & $\begin{array}{c}-0.008 * * * \\
(0.0005)\end{array}$ \\
\hline GDP per capita (constant 2005 US\$), log & $\begin{array}{l}0.06^{* * *} \\
(0.005)\end{array}$ & $\begin{array}{l}0.3^{* * *} \\
(0.01)\end{array}$ & $\begin{array}{l}0.3^{* * *} \\
(0.01)\end{array}$ & $\begin{array}{c}-0.08^{* * *} \\
(0.004)\end{array}$ & $\begin{array}{c}-0.06^{* * *} \\
(0.004)\end{array}$ \\
\hline English Common Law & $\begin{array}{c}0.03 * * * \\
(0.01)\end{array}$ & $\begin{array}{c}0.02 \\
(0.03)\end{array}$ & $\begin{array}{l}0.08^{* *} \\
(0.03)\end{array}$ & $\begin{array}{c}-0.08^{* * *} \\
(0.007)\end{array}$ & $\begin{array}{c}-0.04 \text { *** } \\
(0.009)\end{array}$ \\
\hline Ethnic Fractionalization & $\begin{array}{l}-0.03 \\
(0.02)\end{array}$ & $\begin{array}{c}0.02 \\
(0.07)\end{array}$ & $\begin{array}{l}0.2^{* * *} \\
(0.05)\end{array}$ & $\begin{array}{l}0.2^{* * *} \\
(0.01)\end{array}$ & $\begin{array}{l}0.1^{* * *} \\
(0.02)\end{array}$ \\
\hline Year & $\begin{array}{c}-0.002^{* * *} \\
(0.0005)\end{array}$ & $\begin{array}{c}-0.02 * * * \\
(0.003)\end{array}$ & $\begin{array}{c}-0.008^{* *} \\
(0.003)\end{array}$ & $\begin{array}{l}0.004 * * * \\
(0.0002)\end{array}$ & $\begin{array}{l}0.004 * * * \\
(0.0002)\end{array}$ \\
\hline Dummies for Global Regions & Included & Included & Included & Included & Included \\
\hline
\end{tabular}

Standard errors in parentheses ${ }^{* * *} p<0.001,{ }^{* *} p<0.05$, and ${ }^{*} p<0.1$ refers to $1 \%, 5 \%$, and $10 \%$ significance level, respectively.

\section{Discussion}

Rapid economic, political, and social globalization has led to an increase in the scope and intensity of international pressures on all nations. This is a fact of modern life, but there is debate over whether it is a good or bad thing for most of the world's citizens. Though there are dissident voices, the prevailing account in the literature is that international collaboration encourages domestic politicians to adopt policies that lead to a wide variety of good outcomes, including an improved domestic government (Bauhr and Nasiritousi 2012).

We have presented a more nuanced picture by noting that a particular type of international cooperation-an increasing membership in intergovernmental organizations-is likely to have a mix of good and bad consequences for member states. On the positive side, it helps member states to solve coordination problems and to deal with rapidly changing global demands and expectations in important policy areas such as technology, the economy, and the natural environment. Intergovernmental organizations also help to transmit international norms and standards. They may also provide resources that improve the state capacity of their members. Yet, as we have shown, increasing embeddedness in intergovernmental organizations also has a disruptive effect on domestic governments. Importantly, the negative consequences on the quality of domestic governance are not due to memberships in a few, powerful IGOs (such as the IMF, the WTO, and the World Bank), whose strong effects on domestic governance have already been shown in the literature.

The loss of accountability to citizens is a negative externality that arises as international actors try to exercise more influence over national governments. We emphasize the cost aspect of international cooperation: Increased activities of international organizations unintentionally make it more difficult 
for citizens to control political incumbents. The decline in accountability is likely to contribute to a decline in the quality of government, and our empirical analysis supports this theoretical expectation.

All nations face a trade-off between the advantages of international cooperation and the negative influence of adding international principals (or would be principals) on domestic accountability. Our findings show that there are negative effects for more and less economically developed countries as well as for electoral democracies and nondemocratic countries. In comparison to the argument made by Keohane et al. (2009), we found little evidence that membership in IGOs reduces corruption in member states. The weight of the evidence we present indicates that adding international principals (or would be principals) worsens corruption across a range of states: Democratic, autocratic, OECD, Non-OECD, and Non-EU. Still, it is possible that the "internationalization of domestic politics" affects the policies of countries differently depending upon institutional contexts that affect the incentives of politicians (Gourevitch 1978; Keohane et al. 1996; Hawkins et al. 2006; Fang 2008).

Future research could explore differences in the effects of international cooperation on the quality of government. We anticipate that domestic accountability is affected by: (1) The mix of IGO memberships; (2) the relative ability of different IGOs to enforce compliance; (3) the degree to which particular IGO prescriptions are reinforced or contradicted by the policy preferences of other IGOs; and (4) the degree of support particular IGOS receive from powerful governments in the world. In addition, competition among IGOs may reduce domestic accountability more in some types of policy area and in some types of countries.

Our argument and findings do not imply that international cooperation will have net negative consequences on every policy outcome. The strength of the disruptive effect on specific policy outcomes depends on the balance of costs and benefits, which are likely to vary for different policy areas and types of countries. The costs of international cooperation, depending upon the policy area, may or may not outweigh the benefits. Thus, our contentions are consistent with previous research showing both positive and negative effects of international cooperation. Examples of positive effects include stopping the spread of epidemic disease, providing better sanitation, and improving environmental quality (Frank et al. 2000; Spilker 2012; Clavier and Leeuw 2013). For other policy areas, such as improving human rights practices and stimulating economic development (Abouharb and Cingranelli 2007; Bourguignon and Sundberg 2007; Knack and Rahman 2007), the findings are less conclusive, but some studies show negative consequences. After more findings accumulate, we can refine the theory to better anticipate the characteristics of policies and types of nations where the negative externalities of international cooperation are greatest.

It is likely that states will continue to join IGOs and that the influence of IGOs will increase. Thus, the undermining of domestic accountability is likely to continue. As long as intergovernmental organizations focus on controlling governments, they will undermine the influence of citizens over their own politicians. To counterbalance this effect, intergovernmental organizations should put more efforts into making it more difficult for domestic politicians to shirk their responsibilities to their own citizens. First, major IGOs like the IMF, World Bank, and World Trade Organization should step up their efforts to promote transparency within their member states. Other IGOs should follow suit. However, the current transparency efforts of IGOs are designed mainly to require that national governments reveal more information about their own activities. National governments should also disclose NGO demands. Intergovernmental organizations could also promote domestic policies designed to create or enhance domestic accountability mechanisms. In general, international organizations should adopt measures specifically designed to make it harder for national politicians to blame globalization for their own lack of efforts to improve the quality of government.

Author Contributions: All three authors contributed equally to the conceptualization, methodology, writing, and editing of this paper.

Funding: This research received no external funding.

Conflicts of Interest: The authors declare no conflict of interest. 


\section{Appendix A}

Table A1. List of countries included in the empirical analysis.

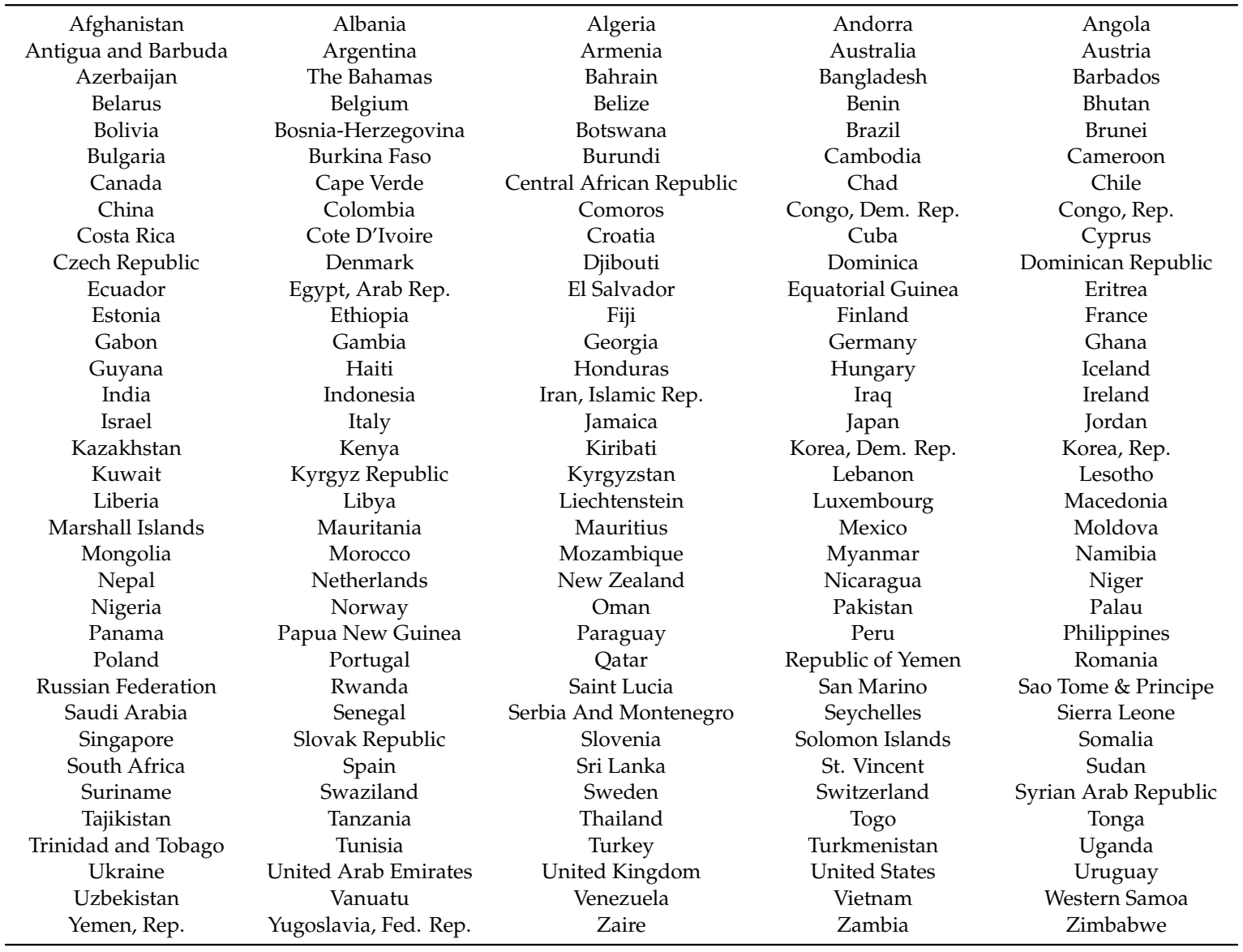

Table A2. Descriptive statistics.

\begin{tabular}{ccccc}
\hline & Mean & S.D. & Min & Max \\
\hline ICRG Indicator of Quality of Government & 0.56 & 0.23 & 0.04 & 1.00 \\
Control of Corruption & -0.05 & 1.01 & -2.06 & 2.59 \\
Government Effectiveness & -0.06 & 1.00 & -2.32 & 2.34 \\
Political corruption & 0.48 & 0.27 & 0.01 & 0.94 \\
Public sector corruption index & 0.48 & 0.30 & 0.01 & 0.97 \\
Number of IGOs Country Participates & 49.2 & 23.6 & 1 & 150 \\
Institutionalized Democracy & 3.99 & 4.22 & 0 & 10 \\
GDP per capita (constant 2005 US\$), log & 7.83 & 1.61 & 4.24 & 11.75 \\
Total natural resources rents (\% of GDP) & 9.66 & 13.52 & 0.00 & 88.05 \\
Economic Globalization & 47.64 & 18.93 & 8.49 & 99.03 \\
English Common Law & 0.18 & 0.38 & 0 & 1 \\
Ethnic Fractionalization & 0.46 & 0.27 & 0 & 1 \\
\hline
\end{tabular}


Table A3. Correlations among independent variables.

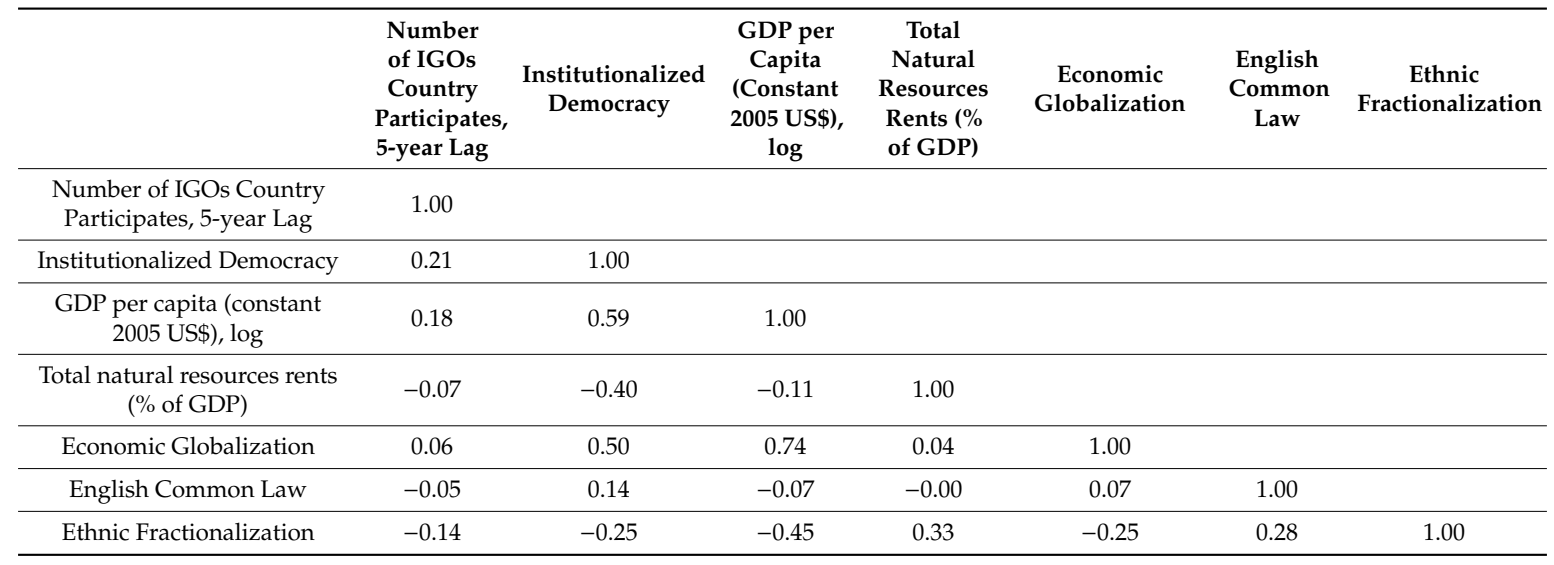

Table A4. Brief descriptions of the five dependent variables used in the analysis.

The quality of government index (provided by the ICRG) is computed as the average value of three ICRG variables: Corruption, law and order, and bureaucracy quality. It is scaled from 0 to 1 with higher values indicating a higher quality of government (Dahlberg et al. 2019).

- The control of corruption index measures perceptions of corruption, defined as the exercise of public power for private gain (provided by the World Bank's Worldwide Government database).

- The government effectiveness index combines variables measuring perceptions of the quality of the bureaucracy and other characteristics of government required for efficient government policies (provided by the World Bank's Worldwide Government database).

- The political corruption index is based on country expert answers to questions about the pervasiveness of political corruption in a variety of government institutions and activities (provided by the Variety of Democracy (V-Dem) Project)

- $\quad$ The public sector corruption index is based on country expert answers to questions about the pervasiveness of public sector corruption (provided by the Variety of Democracy (V-Dem) Project).

\section{References}

Abbott, Kenneth W., and Duncan Snidal. 1998. Why states act through formal international organizations. Journal of Conflict Resolution 42: 3-32. [CrossRef]

Abbott, Kenneth W., Philipp Genschel, Duncan Snidal, and Bernhard Zangl. 2015. International Organizations as Orchestrators. New York: Cambridge University Press.

Abouharb, M. Rodwan, and David Cingranelli. 2007. Human Rights and Structural Adjustment. New York: Cambridge University Press.

Abouharb, M. Rodwan, David L. Cingranelli, and Mikhail Filippov. 2015. Do Non-Human Rights Regimes Undermine the Achievement of Economic and Social Rights? In Closing the Rights Gap: From Human Rights to Social Transformation. Edited by LaDawn Haglund and Robin Stryker. Oakland: University of California Press, pp. 29-48.

Acharya, Arnab, Ana Teresa Fuzzo De Lima, and Mick Moore. 2006. Proliferation and fragmentation: Transactions costs and the value of aid. Journal of Development Studies 42: 1-21. [CrossRef]

Ackman, Dan. 2003. Bush Cuts Steel Tariffs, Declares Victory. Forbes, May 12. Available online: https: //www.forbes.com/2003/12/05/cx_da_1205topnews.html (accessed on 1 February 2019).

Adsera, Alicia, Carles Boix, and Mark Payne. 2003. Are you being served? Political accountability and quality of government. Journal of Law, Economics, and Organization 19: 445-90. [CrossRef]

Aidt, Toke S. 2003. Economic Analysis of Corruption: A Survey. The Economic Journal 113: F632-52. [CrossRef]

Alesina, Alberto, Arnaud Devleeschauwer, William Easterly, Sergio Kurlat, and Romain Wacziarg. 2003. Fractionalization. Journal of Economic Growth 8: 155-94. [CrossRef] 
Alter, Karen J., and Sophie Meunier. 2009. The Politics of International Regime Complexity. Perspectives on Politics 7: 13-24. [CrossRef]

Anderson, Cameron D. 2006. Economic voting and multilevel government: A comparative individual-level analysis. American Journal of Political Science 50: 446-60. [CrossRef]

Barnett, Michael N., and Martha Finnemore. 1999. The politics, power, and pathologies of international organizations. International Organization 53: 699-732. [CrossRef]

Barnett, Michael, and Martha Finnemore. 2004. Rules for the World: International Organizations in Global Politics. Ithaca: Cornell University Press.

Bauer, Michael W., Christoph Knill, and Steffen Eckhard. 2016. International Bureaucracy: Challenges and Lessons for Public Administration Research. New York: Springer.

Bauhr, Monika, and Nicholas Charron. 2018. Insider or Outsider? Grand Corruption and Electoral Accountability. Comparative Political Studies 51: 415-46. [CrossRef]

Bauhr, Monika, and Naghmeh Nasiritousi. 2012. How do international organizations promote quality of government? Contestation, integration, and the limits of IO power. International Studies Review 14: 541-66. [CrossRef]

Bearce, David H., and Stacy Bondanella. 2007. Intergovernmental organizations, socialization, and member-state interest convergence. International Organization 61: 703-33. [CrossRef]

Bernheim, B. Douglas, and Michael D. Whinston. 1986. Common agency. Econometrica: Journal of the Econometric Society 54: 923-42. [CrossRef]

Bourguignon, François, and Mark Sundberg. 2007. Aid effectiveness: opening the black box. The American Economic Review 97: 316-21. [CrossRef]

Bovens, Mark, Robert E. Goodin, and Thomas Schillemans. 2014. The Oxford Handbook Public Accountability. Oxford: Oxford University Press.

Bowler, Shaun. 2017. Trustees, delegates, and responsiveness in comparative perspective. Comparative Political Studies 50: 766-93. [CrossRef]

Broome, André, and Joel Quirk. 2015. Governing the world at a distance: The practice of global benchmarking. Review of International Studies 41: 819-41. [CrossRef]

Busch, Marc L. 2007. Overlapping Institutions, Forum Shopping, and Dispute Settlement in International Trade. International Organization 61: 735-61. [CrossRef]

Canavire-Bacarreza, Gustavo Javier, Eric Neumayer, and Peter Nunnenkamp. 2015. Why aid is unpredictable: An empirical analysis of the gap between actual and planned aid flows. Journal of International Development 27: 440-63. [CrossRef]

Carrubba, Clifford J., and Matthew Gabel. 2017. International Courts: A Theoretical Assessment. Annual Review of Political Science 20: 55-73. [CrossRef]

Charron, Nicholas, and Victor Lapuente. 2010. Does democracy produce quality of government? European Journal of Political Research 49: 443-70. [CrossRef]

Clavier, Carole, and Evelyne de Leeuw, eds. 2013. Health Promotion and the Policy Process. Oxford: OUP Oxford.

Copelovitch, Mark S. 2010. Master or Servant? Common Agency, Preference Heterogeneity, and the Political Economy of IMF Lending. International Studies Quarterly 54: 49-77. [CrossRef]

Dahlberg, Stefan, Sören Holmberg, Bo Rothstein, Natalia Alvarado Pachon, and Richard Svensson. 2019. The Quality of Government Basic Dataset, version Jan19. University of Gothenburg: The Quality of Government Institute. Available online: http://www.qog.pol.gu.sedoi:10.18157/qogbasjan19 (accessed on 19 April 2019).

De Mesquita, Bruce Bueno, Alastair Smith, James D. Morrow, and Randolph M. Siverson. 2005a. The Logic of Political Survival. Cambridge: MIT Press.

De Mesquita, Bruce Bueno, George W. Downs, Alastair Smith, and Feryal Marie Cherif. 2005b. Thinking inside the box: A closer look at democracy and human rights. International Studies Quarterly 49: 439-57. [CrossRef]

Dehousse, Renaud. 2008. Delegation of powers in the European Union: The need for a multi-principals model. West European Politics 31: 789-805. [CrossRef]

Dewatripont, Mathias, Ian Jewitt, and Jean Tirole. 2000. Multitask agency problems: Focus and task clustering. European Economic Review 44: 869-77. [CrossRef]

Dixit, Avinash. 2002. Incentives and organizations in the public sector: An interpretative review. Journal of Human Resources 37: 696-727. [CrossRef] 
Dreher, Axel. 2006. Does Globalization Affect Growth? Evidence from a new Index of Globalization. Applied Economics 38: 1091-110. [CrossRef]

Dreher, Axel. 2009. IMF conditionality: theory and evidence. Public Choice 141: 233-67. [CrossRef]

Dreher, Axel, and Stefan Voigt. 2011. Does membership in international organizations increase governments' credibility? Testing the effects of delegating powers. Journal of Comparative Economics 39: 326-48. [CrossRef]

Dreher, Axel, Christos Kotsogiannis, and Steve McCorriston. 2007. Corruption around the world: Evidence from a structural model. Journal of Comparative Economics 35: 443-66. [CrossRef]

Dreher, Axel, Martin Gassebner, and Lars-HR Siemers. 2012. Globalization, economic freedom, and human rights. Journal of Conflict Resolution 56: 516-46.

Drezner, Daniel W. 2009. The Power and Peril of International Regime Complexity. Perspectives on Politics 7: 65-70. [CrossRef]

Fang, Songying. 2008. The informational role of international institutions and domestic politics. American Journal of Political Science 52: 304-21. [CrossRef]

Fang, Songying, and Erica Owen. 2011. International institutions and credible commitment of non-democracies. The Review of International Organizations 6: 141-62. [CrossRef]

Ferejohn, John. 1999. Accountability and Authority: Toward a Theory of Political Accountability. In Democracy, Accountability, and Representation. Cambridge Studies in the Theory of Democracy. Edited by Adam Przeworski, Susan C. Stokes and Bernard Manin. Cambridge: Cambridge University Press, pp. 131-53.

Fortunato, Piergiuseppe, and Ugo Panizza. 2015. Democracy, education and the quality of government. Journal of Economic Growth 20: 333-63. [CrossRef]

Frank, David John, Ann Hironaka, and Evan Schofer. 2000. The nation-state and the natural environment over the twentieth century. American Sociological Review 65: 96-116. [CrossRef]

Fukuyama, Francis. 2013. What is government? Government 26: 347-68.

Gailmard, Sean. 2009. Multiple principals and oversight of bureaucratic policy-making. Journal of Theoretical Politics 21: 161-86. [CrossRef]

Gartzke, Erik, and Megumi Naoi. 2011. Multilateralism and Democracy: A Dissent Regarding Keohane, Macedo, and Moravcsik. International Organization 65: 589-98. [CrossRef]

Gourevitch, Peter. 1978. The Second Image Reversed: The International Sources of Domestic Politics. International Organization 32: 881-912. [CrossRef]

Grant, Ruth W., and Robert O. Keohane. 2005. Accountability and abuses of power in world politics. American Political Science Review 99: 29-43. [CrossRef]

Greenhill, Brian. 2010. The company you keep: International socialization and the diffusion of human rights norms. International Studies Quarterly 54: 127-45. [CrossRef]

Greenhill, Brian. 2016. Transmitting Rights: International Organizations and the Diffusion of Human Rights Practices. Oxford: Oxford University Press.

Greenhill, Brian, Layna Mosley, and Aseem Prakash. 2009. Trade-Based Diffusion of Labor Rights: A Panel Study, 1986-2002. American Political Science Review 103: 669-90. [CrossRef]

Grigorescu, Alexandru. 2003. International organizations and government transparency: Linking the international and domestic realms. International Studies Quarterly 47: 643-67. [CrossRef]

Gulzar, Saad, and Benjamin J. Pasquale. 2017. Politicians, bureaucrats, and development: Evidence from India. American Political Science Review 111: 162-83. [CrossRef]

Gygli, Savina, Florian Haelg, Niklas Potrafke, and Jan-Egbert Sturm. 2019. The KOF Globalisation Index-Revisited. Review of International Organizations 14: 1-32. [CrossRef]

Hawkins, Darren G., David A. Lake, Daniel L. Nielson, and Michael J. Tierney. 2006. Delegation and Agency in International Organizations. New York: Cambridge University Press.

Heller, William B., Andreas P. Kyriacou, and Oriol Roca-Sagalés. 2016. Institutional checks and corruption: The effect of formal agenda access on government. European Journal of Political Research 55: 681-701. [CrossRef]

Hellwig, Timothy, and David Samuels. 2008. Electoral accountability and the variety of democratic regimes. British Journal of Political Science 38: 65-90. [CrossRef]

Hix, Simon. 2002. Parliamentary behavior with two principals: Preferences, parties, and voting in the European Parliament. American Journal of Political Science 46: 688-98. [CrossRef]

Hobolt, Sara, James Tilley, and Susan Banducci. 2013. Clarity of Responsibility. How Government Cohesion Conditions Performance Voting. European Journal of Political Research 52: 164-87. [CrossRef] 
Holmstrom, Bengt, and Paul Milgrom. 1988. Common Agency and Exclusive Dealing. Yale University, School of Management, Working Paper. Available online: https:/economics.mit.edu/files/3779 (accessed on 1 June 2017).

Holmstrom, Bengt, and Paul Milgrom. 1991. Multitask principal-agent analyses: Incentive contracts, asset ownership, and job design. Journal of Law, Economics, and Organization 7: 24-52. [CrossRef]

Karlsson, Christer, Thomas Persson, and Sverker Gustavsson, eds. 2009. The Illusion of Accountability in the European Union. New York: Routledge Press.

Keohane, Robert O. 2003. Global Government and Democratic Accountability. In Taming Globalization: Frontiers of Government. Edited by David Held and Mathias Koenig-Archibugi. Cambridge: Polity Press, pp. 130-59.

Keohane, Robert O. 2009. The "Second Image Reversed" Revisited. In The Future of Political Science: 100 Perspectives. Edited by Gary King, Kay L. Schlozman and Norman Nie. New York: Routledge, pp. 196-98.

Keohane, Robert O., Helen V. Milner, Peter Lange, and Robert H. Bates. 1996. Internationalization and Domestic Politics. New York: Cambridge University Press.

Keohane, Robert O., Stephen Macedo, and Andrew Moravcsik. 2009. Democracy Enhancing Multilateralism. International Organization 63: 1-31. [CrossRef]

Kilby, Christopher. 2011. What determines the size of aid projects? World Development 39: 1981-94. [CrossRef]

Knack, Stephen. 2001. Aid dependence and the quality of government: cross-country empirical tests. Southern Economic Journal 86: 310-29. [CrossRef]

Knack, Stephen, and Aminur Rahman. 2007. Donor fragmentation and bureaucratic quality in aid recipients. Journal of Development Economics 83: 176-97. [CrossRef]

Koop, Christel, and Chris Hanretty. 2018. Political Independence, Accountability, and the Quality of Regulatory Decision-Making. Comparative Political Studies 51: 38-75. [CrossRef]

La Porta, Rafael, Florencio Lopez-de-Silanes, Andrei Shleifer, and Robert Vishny. 1999. The Quality of Government. Journal of Law, Economics and Organization 15: 222-79. [CrossRef]

Laffont, Jean-Jacques, and David Martimort. 2009. The Theory of Incentives: The Principal-Agent Model. Princeton: Princeton University Press.

Langbein, Laura, and Stephen Knack. 2010. The worldwide governance indicators: Six, one, or none? The Journal of Development Studies 46: 350-70. [CrossRef]

Lederman, Daniel, Norman V. Loayza, and Rodrigo R. Soares. 2005. Accountability and corruption: Political institutions matter. Economics \& Politics 17: 1-35.

Lindstädt, René, Jonathan B. Slapin, and Ryan J. Vander Wielen. 2012. Adaptive behaviour in the European Parliament: Learning to balance competing demands. European Union Politics 13: 465-86. [CrossRef]

Lipson, Michael. 2017. Organization Theory and Cooperation and Conflict among International Organizations. In Palgrave Handbook of Inter-Organizational Relations in World Politics. New York: Springer, pp. 67-96.

Mair, Peter. 2013. Smaghi versus the Parties: Representative Government and Institutional Constraints. In Politics in the Age of Austerity. Edited by Armin Schäfer and Wolfgang Streeck. Cambridge: Polity Press, pp. 143-68.

Mansfield, Edward D., and Jon C. Pevehouse. 2006. Democratization and international organizations. International Organization 60: 137-67. [CrossRef]

Mansfield, Edward D., Helen V. Milner, and B. Peter Rosendorff. 2002. Why democracies cooperate more: Electoral control and international trade agreements. International Organization 56: 477-513. [CrossRef]

Manzetti, Luigi, and Carole J. Wilson. 2007. Why do corrupt governments maintain public support? Comparative Political Studies 40: 949-70. [CrossRef]

Marshall, Monty G., Ted Robert Gurr, and Keith Jaggers. 2018. Polity IV Project: Political Regime Characteristics and Transitions, 1800-2017. Dataset Users' Manual. Available online: http://www.systemicpeace.org/polity (accessed on 19 October 2018).

Mauro, Paolo. 1995. Corruption and growth. The Quarterly Journal of Economics 110: 681-712. [CrossRef]

Merry, Sally Engle, Kevin E. Davis, and Benedict Kingsbury. 2015. The Quiet Power of Indicators: Measuring Government, Corruption, and Rule of Law. New York: Cambridge University Press.

Meyer, Lisa B. 2003. Economic globalization and women's status in the labor market: A cross-national investigation of occupational sex segregation and inequality. The Sociological Quarterly 44: 351-83. [CrossRef]

Moravcsik, Andrew. 1994. Why the European Community Strengthens the State: Domestic Politics and International Cooperation. Cambridge: Minda de Gunzburg Center for European Studies, Harvard University.

Moravcsik, Andrew. 2000. The origins of human rights regimes: Democratic delegation in postwar Europe. International Organization 54: 217-52. [CrossRef] 
Neumayer, Eric, and Indra de Soysa. 2011. Globalization and the empowerment of women: An analysis of spatial dependence via trade and foreign direct investment. World Development 39: 1065-75. [CrossRef]

Orsini, Amandine, Jean-Frédéric Morin, and Oran Young. 2013. Regime Complexes: A Buzz, a Boom, or a Boost for Global Governance. Global Governance 19: 27-39. [CrossRef]

Papadopoulos, Yannis. 2010. Accountability and multi-level government: More accountability, less democracy? West European Politics 33: 1030-49. [CrossRef]

Pellegrini, Lorenzo. 2011. Causes of corruption: A survey of cross-country analyses and extended results. In Corruption, Development and the Environment. New York: Springer, pp. 29-51.

Pellegrini, Lorenzo, and Reyer Gerlagh. 2008. Causes of corruption: A survey of cross-country analyses and extended results. Economics of Governance 9: 245-63. [CrossRef]

Pevehouse, Jon C. 2002. With a little help from my friends? Regional organizations and the consolidation of democracy. American Journal of Political Science 46: 611-26. [CrossRef]

Pevehouse, Jon, Timothy Nordstrom, and Kevin Warnke. 2004. The Correlates of War 2 international governmental organizations data version 2.0. Conflict Management and Peace Science 21: 101-19. [CrossRef]

Potrafke, Niklas. 2015. The evidence on globalisation. The World Economy 38: 509-52. [CrossRef]

Powell, G. Bingham, and Guy D. Whitten. 1993. A cross-national analysis of economic voting: Taking account of the political context. American Journal of Political Science 37: 391-414. [CrossRef]

Przeworski, Adam, Susan C. Stokes, and Bernard Manin, eds. 1999. Democracy, Accountability, and Representation. Cambridge Studies in the Theory of Democracy. Cambridge: Cambridge University Press.

Putnam, Robert D. 1988. Diplomacy and domestic politics: The logic of two-level games. International Organization 42: 427-60. [CrossRef]

Raustiala, Kal, and David G. Victor. 2004. The Regime Complex for Plant Genetic Resources. International Organization 58: 277-309. [CrossRef]

Richards, David L., and Ronald Gelleny. 2007. Women's status and economic globalization. International Studies Quarterly 51: 855-76. [CrossRef]

Rothstein, Bo O., and Jan A. N. Teorell. 2008. What is quality of government? A theory of impartial government institutions. Government 21: 165-90. [CrossRef]

Sanger, David E., and Joseph Kahn. 2002. Bush Weighs Raising Steel Tariffs but Exempting Most Poor Nations. New York Times, March 4.

Scharpf, Fritz W. 2013. Political Legitimacy in a Non-Optimal Currency Area. KFG Working Paper 52. Berlin: Freie Universität Berlin.

Schedler, Andreas. 1999. Conceptualizing Accountability. In The Self-Restraining State: Power and Accountability in New Democracies. Edited by Andreas Schedler, Larry Jay Diamond and Marc F. Plattner. London: Lynne Rienner Publishers, pp. 13-28.

Sinclair-Desgagné, Bernard. 2001. Incentives in Common Agency. Cahier de Recherche no IEA. Montreal: École des Hautes Études Commerciales.

Smith, Brian Clive. 2007. Good Government and Development. London: Palgrave Macmillan.

Spilker, Gabriele. 2012. Helpful organizations: Membership in inter-governmental organizations and environmental quality in developing countries. British Journal of Political Science 42: 345-70. [CrossRef]

Sundell, Anders. 2015. Stability and Stagnation. In Elites, Institutions and the Quality of Government. London: Springer, pp. 129-46.

Tavits, Margit. 2007. Clarity of responsibility and corruption. American Journal of Political Science 51: 218-29. [CrossRef]

Tran, Mark. 2003. Bush lifts steel tariffs to avert trade war. The Guardian, December 4. Available online: https://www.theguardian.com/world/2003/dec/04/usa.wto1 (accessed on 1 December 2018).

Treisman, Daniel. 2000. The causes of corruption: A cross-national study. Journal of Public Economics 76: 399-457. [CrossRef]

Von Stein, Jana. 2016. Making promises, keeping promises: Democracy, ratification and compliance in international human rights law. British Journal of Political Science 46: 655-79. [CrossRef]

Vreeland, James Raymond. 2003. Why do governments and the IMF enter into agreements? Statistically selected cases. International Political Science Review 24: 321-43. [CrossRef]

Waltz, Kenneth N. 1999. Globalization and government. PS: Political Science E Politics 32: 693-700. 
World Bank. 2018. World Development Indicators. Available online: https://databank.worldbank.org/data/source/ world-development-indicators (accessed on 1 December 2018).

Young, Oran R. 2011. Effectiveness of international environmental regimes: Existing knowledge, cutting-edge themes, and research strategies. Proceedings of the National Academy of Sciences of the United States of America 108: 19853-60. [CrossRef] [PubMed] 